\title{
ANALISIS PENTRANSMISIAN FIBER OPTIK SALURAN UDARA PADA PANJANG GELOMBANG 1310 nm Dari Optical Distribution Point (ODP) - Optical Network Termination (ONT)
}

\author{
Ahmad Muharor ${ }^{1}$, Bambang PanjiAsmara ${ }^{2}$, Zainudin Bonok $^{3}$ \\ ${ }^{123}$ Prodi Teknik Elektro, Fakultas Teknik, Universitas Negeri Gorontalo \\ Jl. Jend. Sudirman No.6 Kota Gorontalo 96128 Indonesia \\ Email : Ahmadmuharor354@gmail.com, Bambang@ung.ac.id, zainudinbonok@ung.ac.id
}

\begin{abstract}
ABSTRAK
Fiber optik adalah saluran transmisi yang terbuat dari kaca atau plastik yang digunakan untuk mentransmisikan sinyal cahaya dari suatu tempat ke tempat lain. Struktur dan komponen kabel fiber optik yaitu Inti (coreloptical fibers), bagian utama yang terbuat dari serat kaca, berada dibagian pusat kabel.

Dalam penelitian ini, pengukuran dilakukan pada fiber optik saluran udara pada panjang gelombang $1310 \mathrm{~nm}$ dengan jarak 100 meter hingga 350 meter. Penelitian ini dilakukan dengan mengukur daya kirim pada ODP (Optical Distribution Point), daya terima pada ONT (Optical Network Termination) yang ada di pelanggan, serta total loss yang terjadi di sepanjang kabel.

Dari hasil pengukuran yang dilakukan dapat disimpulkan bahwa dengan jarak 100 meter sampai 350 meter diperoleh nilai daya terima yang berkisaran antara -18.729 dB sampai dengan $24.796 \mathrm{~dB}$ dan nilai total loss yang berada pada kisaran $0.634 \mathrm{~dB}$ sampai dengan $0.751 \mathrm{~dB}$.

Kata Kunci: Fiber Optik, Optical Distribution Point (ODP), Optical Network Termination (ONT)
\end{abstract}

\section{PENDAHULUAN}

Di era modern seperti saat ini, perkembangan teknologi telekomunikasi mengalami kemajuan yang sangat pesat, yang disebabkan oleh adanya suatu permintaan dan juga meningkatnya kebutuhan akan informasi yang sangat tinggi dan akan terus meningkat. Hal ini membuat pengembang harus meningkatkan kualitas dari suatu media transmisi baik kualitas sinyal, area cakupan penerima yang luas, waktu akses, keamanan data pengguna, serta harga jual yang terjangkau, guna memenuhi kebutuhan telekomunikasi tersebut.

Teknologi fiber optik merupakan salah satu media transmisi yang dewasa ini semakin berkembang dan semakin meningkat permintaan di pasaran di karenakanmemilikibeberapakeunggulan, antara lain memiliki bandwidth yang besar (25 THz), redaman transmisi kecil, ukuran kecil, dan tidak terpengaruholehgelombang elektromagnetis.

Fiber optik merupakan media transmisi menggunakan cahaya sebagai penyalur informasi (data).

Seiring dengan peningkatan dan pengembangan menggunakan kabel fiber optik sebagai media transmisi data, maka juga sering terjadi faktor hilangnya informasi yang diakibatkan oleh rugi-rugi yang terjadi disepanjang kabel fiber optik, salah satu rugi-rugi tersebut adalah rugi 
daya yang diakibatkan oleh redaman di sepanjang kabel fiber optik, yang mengakibatkan perubahan daya dari pemancar optik (Transmitter) hingga mencapai di penerima optik (Receiver). Perubahan daya tersebut yaitu adanya pelemahan dari daya pemancar optik (Transmitter) sampai di penerima optik (Receiver)

\section{METODE PENELTIAN}

\section{Proses Penelitian}

Penelitian ini dilaksanakan di PT. Telkom Indonesia Wilayah Gorontalo. Adapun cara penelitian dilakukan dengan pengambilan data dilapangan pada pemasangan pelanggan baru. Penelitian dilakukan dengan melakukan pengukuran pada ODP dan ONT. Pengukuran pada ODP dilakukan dengan tujuan untuk mengetahui daya kirim dan redaman yang terdapat pada ODP. Sementara pengukuran pada ONT dilakukan dengan tujuan untuk mengetahui besar daya terima dan redaman input yang terdapat pada ONT. Dengan demikin kita dapat mengetahui berapa selisih antara redaman yang terdapat pada ODP dengan ONT. Sementara alat yang digunakan adalah OPM (Optical Power Meter).

\section{Spesifikasi Parameter Data}

Adapun spesifikasi dari parameter data yang di butuhkan seperti tabel 1 sebagai berikut:

Tabel 1 Spesifikasi Teknis Kabel Serat Optik Tipe Single Mode

\begin{tabular}{|c|c|}
\hline Karakteristik & Nilai \\
\hline $\begin{array}{c}\text { Mode Field Diameter ( } \\
1310 \mathrm{~nm} \text { ) }\end{array}$ & $0,5 \mu \mathrm{m}$ \\
\hline $\begin{array}{c}\text { Diameter Cladding ( } 1310 \\
\mathrm{~nm} \text { ) }\end{array}$ & $2 \mu \mathrm{m}$ \\
\hline $\begin{array}{c}\text { Attenuasi maksimum pada } \\
1310 \mathrm{~nm}\end{array}$ & $0,4 \mathrm{~dB} / \mathrm{km}$ \\
\hline $\begin{array}{c}\text { Rugi-rugi Splice } \\
\text { Rugi-rugi konektor }\end{array}$ & $0,2 \mathrm{~dB} / \mathrm{Km}$ \\
\hline Redaman Fiber Pigtail & $0,2 \mathrm{~dB}$ \\
\hline Redaman Patch cord & $0.02 \mathrm{~dB}$ \\
\hline
\end{tabular}

Dari sumber Tabel 1 dapat diambil beberapa parameter-parameter yang menjadi acuan untuk melakukan sebuah Analisis pentransmisian fiber optik saluran udara pada panjang gelombang $1310 \mathrm{~nm}$. Berikut adalah tabel parameter yang ditunjukkan pada Tabel 2 berikut ini: 
Tabel 2 Parameter - Parameter Yang Digunakan Dalam Analisis

\begin{tabular}{|c|c|c|c|}
\hline \multirow{2}{*}{ No } & \multicolumn{3}{|c|}{ Panjang gelombang 1310 nm } \\
\cline { 2 - 4 } & Parameter & Jumlah & Satuan \\
\hline 1 & Power transmit & $\begin{array}{c}-14.20 \mathrm{~s} / \mathrm{d}- \\
18.76\end{array}$ & $\mathrm{~dB}$ \\
\hline 2 & Safety margin & 3 & $\mathrm{~dB}$ \\
\hline 3 & Pmin & -25 & $\mathrm{~dB}$ \\
\hline 4 & Jarak & $50-300$ & $\mathrm{M}$ \\
\hline 5 & Loss attenuasi & 0.4 & $\mathrm{~dB} / \mathrm{Km}$ \\
\hline 6 & Rugi Splice & $0.1-0.3$ & $\mathrm{~dB} / \mathrm{Km}$ \\
\hline 7 & Rugi Konektor & 0.2 & $\mathrm{~dB}$ \\
\hline 8 & Other Loss & $0.02-0.04$ & $\mathrm{~dB}$ \\
\hline
\end{tabular}

\section{HASIL DAN ANALISIS}

\section{Analisis Sistem Transmisi}

Pada suatu komunikasi khususnya dalam sistem komunikasi fiber optik, suatu informasi misalnya data yang telah disampaikan dengan membutuhkan daya yang sangat besar dari sisi pengirim seharusnya sama dengan daya yang diterima dari sisi penerima. Namun pada kondisi sebenarnya daya akan melemah sepanjang jauhnya jarak yang dilewati oleh optik yang dikenal dengan fiber losses.

\section{Analisis Hasil Penelitian}

Jarak merupakan salah satu faktor yang menyebabkan timbulnya redaman,karena pada jarak tertentu dalam sistem komunikasi fiber optik akan menghasilkan attenuasi. Semakin besar jarak antara pengirim ke penerima, maka akan semakin besar pula attenuasi yang dihasilkan. Selain jarak, ketidak telitian penyambungan juga dapat berpengaruh terhadap meningkatnya loss attenuasi, sehingga akan menyebabkan melemahnya daya terima pada ONT atau pelanggan. Hal ini dikarenakan tinggi rendahnya nilai suatu loss attenuasi pada sistem transmisi sangat mempengaruhi kualitas daya yang diterima oleh pelanggan.

\section{Hasil Total loss (rugi-rugi transmisi) \\ pada media transmisi}

Apabila loss pada media transmisi ini semakin besar akan mengakibatkan sistem akan mengalami kerusakan sehingga tidak ada informasi yang diterima dibagian penerima. Secara hitungan matematika sederhana total loss dapat dihitung sebagai berikut :

Total Loss $=$ loss attenuasi + loss splace + loss konektor + other loss

Dimana :

Loss attenuasi $=$ Redaman fiber $0.4 / \mathrm{Km}$

Loss splace $=$ Redaman pada sambungan 0.1-0.3 dB / Splice.

Loss konektor $=$ redaman pada konektor $=$ $0.2 \mathrm{~dB} /$ Konektor.

Other Loss $=$ Loss lainnya, disini peneliti menggunakan 
Pigtail sebagaikonektor tambahandengan redaman $0.04 \mathrm{~dB} /$ Pigtail.

Untuk panjang gelombang $1310 \mathrm{~nm}$ total loss dapat dihitung sebagai berikut

Pengukuran total loss dari ODP ke ONT yang berada pada Jl. Rambutan, Kel. Buladu, Kec. Kota Barat dengan jarak 100 meter

Total Loss $=$ L.Attenuasi + L. Splice + L. Konektor + Other Loss

Diketahui :

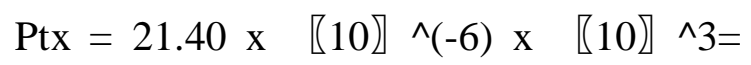
$0.0214 \mathrm{~mW}$

$=10 \log (0.0214 \times$ \ $10 \rrbracket \wedge(-3))$

$=-16.69 \mathrm{dBm}$

Jarak $=100 \mathrm{mx}$ \10】^(-3)

$=0.1 \mathrm{Km}$

$=\frac{0.4 \times 100}{1000}=0.04 \mathrm{~dB}$

L. Attenuasi $=(0.04 * 0.1)=0.004 \mathrm{~dB}$

L. Splice $1=(0.2 * 0.1)=0.02 \mathrm{~dB}$

L. Splice $2=\left(0.1^{*} 0.1\right)=0.01 \mathrm{~dB}$

L. Konektor $=0.2 \mathrm{~dB}$

Other Loss $=0.4 \mathrm{~dB}$

Maka:

Total Loss $=$ L.Attenuasi + L. Splice $1+$ L. Splice $2+$ L. Konektor + Other Loss

$=0.004 \mathrm{~dB}+0.02 \mathrm{~dB}+0.01 \mathrm{~dB}$

$+0.2 \mathrm{~dB}+0.4 \mathrm{~dB}$

$=0.634 \mathrm{~dB}$

\section{Hasil Daya Terima}

Secara hitungan matematika sederhana daya terima dapat dihitung sebagai berikut

$$
\text { P_r =P_t-C_l-M_s (dB) }
$$

Dimana,

$\mathrm{P}(\mathrm{i})=\mathrm{P} \_\mathrm{t}$ =Daya sinyal yang dikirim $(\mathrm{dB})$

$\mathrm{P} \_\mathrm{o}=\mathrm{P} \_\mathrm{r}=$ Daya sinyal diterima receiver $(\mathrm{dB})$

C_1 = Total loss saluran $(\mathrm{dB})$

M_s= Safety Margin (dB)

Untuk panjang gelombang $1310 \mathrm{~nm}$ daya terima dapat dihitung sebagai berikut:

Pengukuran daya terima dari ODP ke ONT yang berada pada Jl. Rambutan, Kel. Buladu, Kec. Kota Barat dengan jarak 100 meter.

P_r $=$ P_t-C_l-M_(s ) (dB)

Diketahui :

$$
\begin{aligned}
\mathrm{Pt} & =21.40 \mathrm{x} \square 10 \rrbracket \wedge(-6) \times \llbracket 10^{\wedge} 3 \\
& =0.0214 \mathrm{~mW} \\
& =10 \log (0.0214 \times \llbracket 10 \rrbracket \wedge(-3)) \\
& =-16.69 \mathrm{dBm} \\
M_{S} & =3 \mathrm{~dB}
\end{aligned}
$$

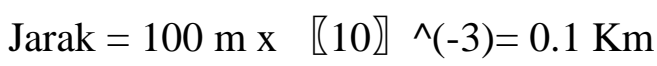

$C_{l}=0.634 \mathrm{~dB}$

Maka :

$$
\begin{aligned}
P_{r} & =\mathrm{P} \_\mathrm{t}-\mathrm{C} \_ \text {l-M_s }(\mathrm{dB}) \\
& =-16.69 \mathrm{dBm}-0.634 \mathrm{~dB}-3 \mathrm{~dB}
\end{aligned}
$$




$$
=-20.324 \mathrm{~dB}
$$

Pada perhitungan diatas terdapat selisi tegangan antara daya kirim pada ODP dan daya terima pada ONT dengan selisi daya $-3.634 \mathrm{~dB}$, hasil dari daya terima di kurang daya kirim.

\section{KESIMPULAN}

Dari hasil penelitian yang dilakukan di PT. Telkom Indonesia Wilayah Gorontalo maka dapat diambil kesimpulan sebagai berikut :

1. Dari hasil pengukuran daya kirim dan perhitungan total loss yang telah dilakukan dapat disimpulkan bahwa dengan panjang kabel serat optik 100 meter sampai dengan 350 meter dapat diperoleh hasil daya terima pada ONT yaitu sebesar -18,79 sampai dengan 24,85. Hasil ini barada pada standar maksimum yang di terapkan di Telkom yaitu berada pada kisaran -15 dB sampai dengan $-25 \mathrm{~dB}$ pada ONT dengan persentase redaman berada pada kisaran $53.6 \%$, sehingga masih berada pada standar kelayakan.

2. Nilai total loss dapat berubah sesuai jarak dan banyaknya jumlah loss yang terdapat disepanjang kabel optik. hal ini dikarenakan untuk mengetahui jumlah total kita harus menjumlahkan loss atttenuasi + loss splice + loss konektor + other loss.
3. Dari hasil penelitian terdapat perbedaan antara daya kirim dari ODP dengan daya terima pada ONT hal ini dikarenakan adanya rugi-rugi daya di sepanjang kapbel. Dari hasil pengukuran pada kabel dengan panjang 100 meter sampai dengan 350 meter terdapat rugi-rugi daya kirim yang berada pada kisaran -3.634 sampai dengan -3.719 dB.

\section{DAFTAR PUSTAKA}

[1] Ade Nurhayat ST.,MT, Kikie Noor Rezky, Akademi Telkom Jakarta (2017).Pengukuran kualitas Transmisi Serat Optik PT.Telkom Pada Ruas Telkom KotamobaguUpai.(http://ejournal.akademitelkom.a c.id/index.php/ictjurnal/article/downlo ad/89/70). Diakses pada tanggal 02 Mei 2018 (20.03)

[2] Adhiguna, B. 2015. Fiber To The Home (FTTH) http://accessbima.blogspot.com/2015/ 07/fiber-to-home-ftth.html. 11 Juni 2018 (09:35)

[3] Dermawan. B, Imam Santoso, dkk (2016), “Analisis Jaringan FTTH (Fiber To The Home) .(https://ejournal.undip.ac.id/index.ph p/transmisi/article/download/10893/8 618) diakses pada tanggal $02 \mathrm{Mei}$ $2018(20: 21)$ 
[4] Fiber optik

https://id.wikipedia.org/wiki/Serat_opt

ik) diakses pada tanggal 16 Maret

$2018(16: 21)$

[5] Hadiwahyudi, E. 2015. Pemasangan

Perangkat Optical Distribution Point

(ODP)

http://tjakraagungpersada.blogspot.co m/2015/08/pemasangan-perangkat-

optical.html. 10 Juni 2018 (22:03)

[6] Heprilian Luchinda .2015. analisis kinerja jaringan serat optik pada ring 1 di Jatinegara

(https://www.slideshare.net/Uofa_Uns ada/analisis-kinerja-jaringan-seratoptik-pada-ring-1-di-arnet-jatinegara) diakses pada tanggal 31 Januari 2018 $(16: 44)$

[7] Ignatius Yoslan Kurniawan (2014) Analisis dan Simulasi Perancangan Jaringan Fiber To The Home (FTTH) Pada Perumahan Buah Batu Square Bandung Menggunakan Optisystem (https://www.researchgate.net/publica tion/286916343_analisis dan simulasi perancangan fiber to the home FTTH pada perumahan buah batu square bandung menggunakan optysystem) diakses pada tanggal 02 Februari 2018 (20:12)

[8] Perdana, A, R. 2017. ONT (Optical Network Termination) http://pengelolaaninstalasikomputerperdana.blogspot.com/2017/04/ont- optical-network-termination.html. 10 Juni 2018 (22:14)

[9] Puti Mayangsari Fhatony, Naemah Mubarakah .2015. Analisis Link Budget Jaringan Serat OptikGigabit Passive Optical Network (https://jurnal.usu.ac.id/index.php/sing uda_ensikom/article/viewFile/10106/5 398) 10 Juni 2018 (22:14)

[11] Sembara P. Toago, Alamsyah, Ardi Amir. 2014. Perancangan Jaringan Fiber To the Home (ftth) Berteknologi Gigabit Passive Optical Network (gpon) di Perumahan Citraland palu (http://jurnal.untad.ac.id/jurnal/index.p hp/Mektrik/article/viewFile/3189/2253 ) Diakses pada tamggal 16 Maret 2018

[12] Yantesa Tri Nanda. 2011, "Simulasi Perbandingan Penguatan Pada Panjang gelombang $1310 \mathrm{~nm}$ dengan penguatan Pada Panjang Gelombang 1550 nm Dalam Komunikasi Serat Optik" Jurusan Teknik Elektro Program Studi Teknik Telekomunikasi Fakultas Sains dan Teknologi Universitas Islam Negeri Riau (2011). 